\title{
Mass budget of the grounded ice in the Lambert Glacier-Amery Ice Shelf system
}

\author{
WEN Jiahong, ${ }^{1}$ WANG Yafeng, ${ }^{1}$ LIU Jiying, ${ }^{1}$ Kenneth C. JEZEK, ${ }^{2}$ \\ Philippe HUYBRECHTS, ${ }^{3}$ Beata M. CSATHÓ, ${ }^{2}$ \\ Katy L. FARNESS, ${ }^{2}$ SUN Bo ${ }^{4}$ \\ ${ }^{1}$ Department of Geography, Shanghai Normal University, Shanghai 200234, China \\ E-mail: jhwen@shnu.edu.cn \\ ${ }^{2}$ Byrd Polar Research Center, The Ohio State University, 1090 Carmack Road, Columbus, OH 43210-1002, USA \\ ${ }^{3}$ Departement Geografie, Vrije Universiteit Brussel, Pleinlaan 2, B-1050 Brussels, Belgium \\ ${ }^{4}$ Polar Research Institute of China, Shanghai 200129, China
}

\begin{abstract}
We used remote-sensing and in situ measurements of surface accumulation rate, ice surface velocity, thickness and elevation to evaluate the mass budgets of grounded ice-flow regimes that form the Lambert Glacier-Amery Ice Shelf system. Three distinct drainage regimes are considered: the western and eastern margins of the ice shelf, and the southern grounding line at the major outlet glacier confluence, which can be identified with drainage zones 9,11 and 10 respectively of Giovinetto and Zwally (2000). Our findings show the entire grounded portion of the basin is approximately in balance, with a mass budget of $-4.2 \pm 9.8 \mathrm{Gta}^{-1}$. Drainages 9,10 and 11 are within balance to the level of our measurement uncertainty, with mass budgets of $-2.5 \pm 2.8 \mathrm{Gt} \mathrm{a}^{-1},-2.6 \pm 7.8 \mathrm{Gt} \mathrm{a}^{-1}$ and $0.9 \pm 2.3 \mathrm{Gt} \mathrm{a}^{-1}$, respectively. The region upstream of the Australian Lambert Glacier basin (LGB) traverse has a net mass budget of $4.4 \pm 6.3 \mathrm{Gt} \mathrm{a}^{-1}$, while the downstream region has $-8.9 \pm 9.9 \mathrm{Gt} \mathrm{a}^{-1}$. These results indicate that glacier drainages 9, 10 and 11, upstream and downstream of the Australian LGB traverse, are in balance to within our measurement error.
\end{abstract}

\section{INTRODUCTION}

During the 1980s and 1990s, several investigators proposed that climate warming would increase snowfall to Antarctica. Increased water storage within the ice sheet would then mitigate sea-level rise (e.g. Connolley and King, 1993; Thompson and Pollard, 1997; Wen, 1998). However, recent studies show that flow speed has increased for some Antarctic outlet glaciers, resulting in increased mass losses from the ice sheet independent of changes in surface accumulation rate (e.g. Payne and others, 2004; Shepherd and others, 2004; Thomas and others, 2004; Wang and others, 2006b). The increased discharge has likely contributed to sea-level rise over the last decade (Solomon and others, 2007). In this paper, we assess the mass budget of grounded ice in the Lambert Glacier-Amery Ice Shelf system (LAS) which drains a substantial portion of the East Antarctic ice sheet. Following Bindschadler and others (1993), we use a geographic information system (GIS) environment to combine a variety of datasets derived from in situ measurements and remote-sensing datasets.

Located at $68.5-81^{\circ} \mathrm{S}, 40-95^{\circ} \mathrm{E}$, the LAS is one of the largest glacier-ice-shelf systems in Antarctica, and is an important drainage basin in terms of the overall mass balance of Antarctica (Fricker and others, 2000b). The LAS consists of western, central (including Lambert, Mellor and Fisher Glaciers) and eastern regions, which correspond to drainages 9, 10 and 11 (as geographically defined by Giovinetto and Zwally, 2000; Zwally and others, 2005) (Fig. 1). We delineated the boundaries of the three drainages by tracing flow stripes (Wu and Jezek, 2004) or foliation trends (Hambrey and Dowdeswell, 1994) observed in the RADARSAT-1 Antarctic Mapping Project image mosaic for the lower-elevation portion (lower than around 2000$2500 \mathrm{~m}$ ), and then tracing the steepest descent paths generated from the Ohio State University (OSU) digital elevation model (DEM) (Liu and others, 1999). The grounding line of the LAS, defined by Fricker and others (2002), is updated using several datasets including (1) the southern grounding-line position of the Amery Ice Shelf mapped by interferometric synthetic aperture radar (InSAR) (Rignot, 2002), (2) velocities with a spacing interval of 400 by $400 \mathrm{~m}$ derived from the Modified Antarctic Mapping Mission (MAMM) InSAR project (Jezek, 2003), and (3) a RADARSAT coherence image map that shows shear margins clearly in some sections (Wen and others, 2007, fig. 2). The whole LAS grounded-ice region has an area of $1.34 \times 10^{6} \mathrm{~km}^{2}$.

Fricker and others (2000b) and Wen and others (2007) summarized previous mass-balance studies in the LAS grounded ice. Previous studies have focused mainly on the central portion (e.g. Allison, 1979; Bentley and Giovinetto, 1991; Rignot, 2002; Wen and others, 2007). In addition, Fricker and others (2000b) and Wen and others (2006) assessed the mass budgets at high elevations upstream of the Australian National Antarctic Research Expedition (ANARE) Lambert Glacier basin (LGB) traverse, which contains regions upstream of drainages 9 and 11 (Fig. 1). In this paper, we estimate the ice fluxes across the grounding lines and total accumulations in drainages 9 and 11 . Then we combine results from Wen and others $(2006,2007)$ to evaluate the mass budget of several sub-basins which divide upstream and downstream portions of the catchment areas. Our objective is to study the mass balance of the entire system and to determine whether there are local variabilities in the mass budget between separate flow regimes. 


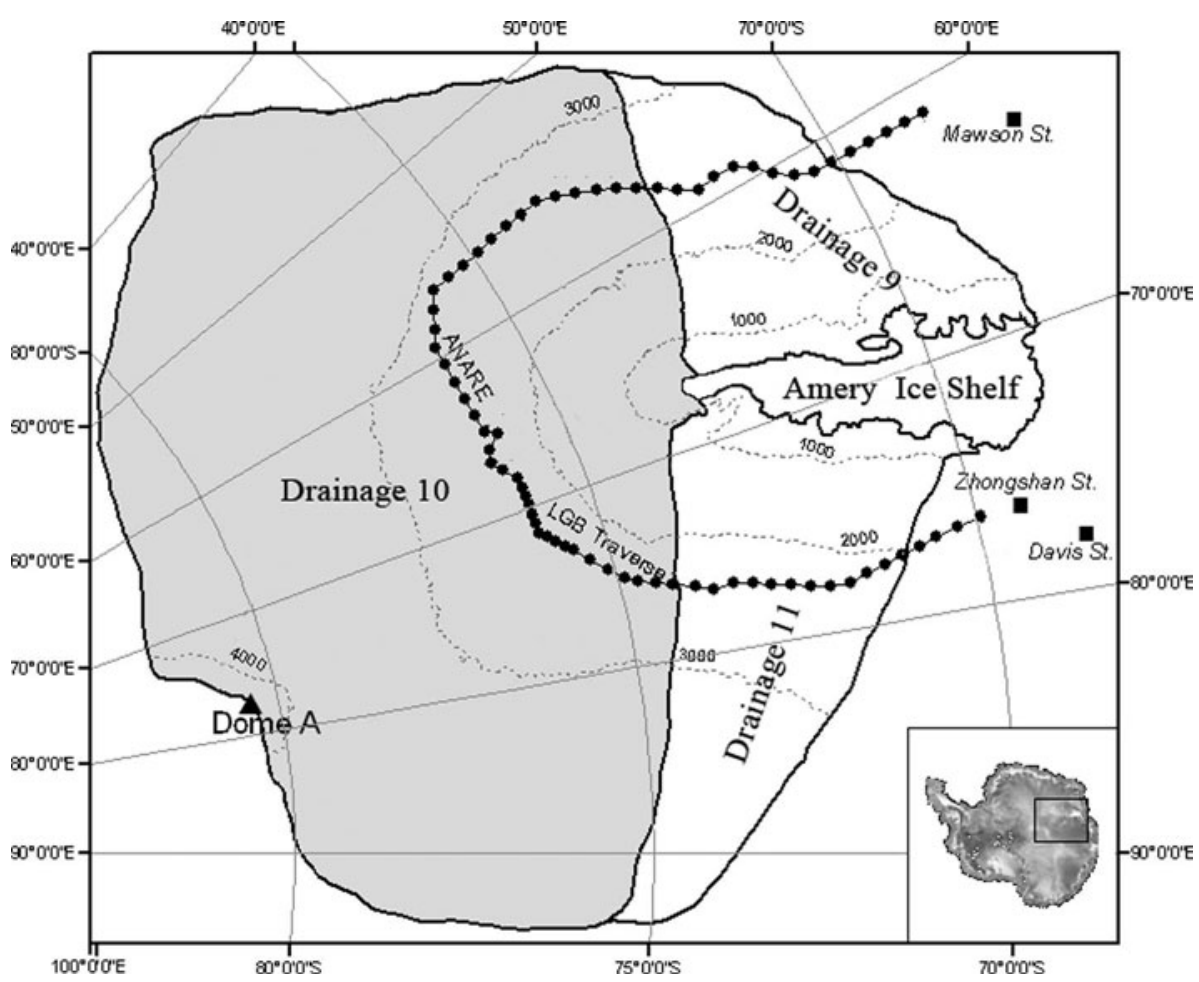

Fig. 1. Map of the LAS, showing the location of drainages 9, 10 (in grey) and 11, and the ANARE LGB traverse route. Elevation contours are shown as dashed lines with a $1000 \mathrm{~m}$ interval.

\section{ICE FLUXES ACROSS GROUNDING LINES AND TOTAL ACCUMULATION IN DRAINAGES 9 AND 11}

\section{Ice fluxes across grounding lines}

The datasets used to assess the output across the grounding line of the LGB include MAMM InSAR surface velocities (Jezek, 2002, 2003; Wen and others, 2007), ice-thickness and column-averaged ice-density data (Wen and others, 2007). Ice-thickness data at the grounding line are deduced from the Amery Ice Shelf DEM using the hydrostatic equation. The DEM, generated by Fricker and others (2000a), is modified by incorporating Ice, Cloud and land Elevation Satellite (ICESat) Geoscience Laser Altimeter System (GLAS) data (Wang and others, 2006a). Typical errors in most of these datasets are discussed by $\mathrm{Wu}$ and Jezek (2004) who also discuss how the errors propagate in a mass flux calculation.
Wen and others (2007) estimated ice flux across the grounding line in drainage 10 . Twelve easterly and nineteen westerly gates (Fig. 2) are placed along the grounding lines across drainages 11 and 9, and the ice fluxes for each of the gates are listed in Table 1.

The error sources in our ice-flux estimates include the uncertainties in ice thickness and InSAR velocity. In this area, ice surface velocity is estimated to be in error by $\pm 10 \mathrm{~m} \mathrm{a}^{-1}$. The low uncertainty is justified based on excellent agreement between the direction of InSAR velocity vectors and the orientation of flow stripes on SAR imagery. It is unlikely that both components of the velocity vector could be substantially in error and in such a way as to retain the expected flow direction. The ice thickness is computed by applying isostasy to the elevation data. Error sources include the uncertainty in the original DEM, column-averaged ice density and the geoid model (Wen and others, 2007).

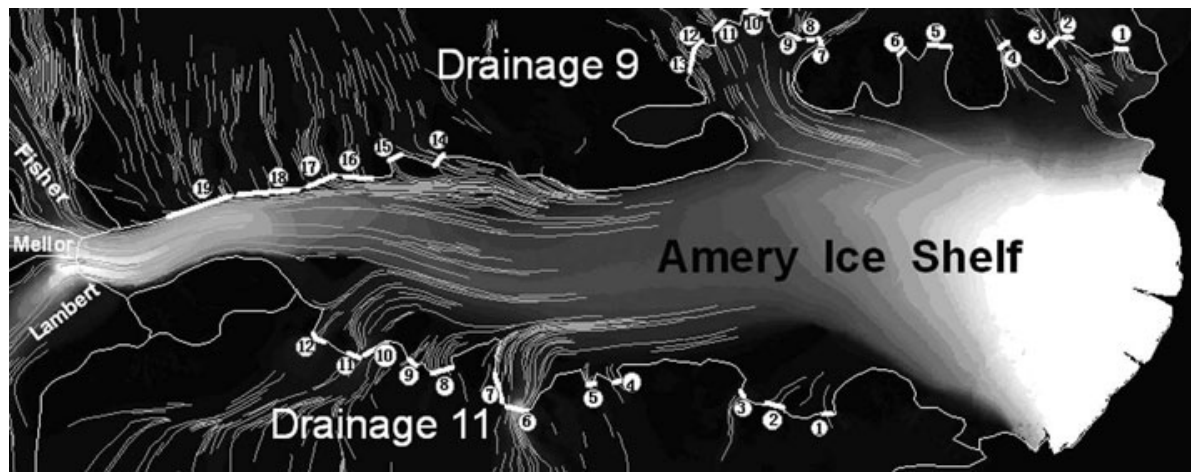

Fig. 2. Map showing the gates (thick white line) and their numbering for calculating ice fluxes across the grounding lines in drainages 9 and 11. Flow stripes (Wu and Jezek, 2004) are in light grey; background is the MAMM InSAR velocity. 
Table 1. Ice fluxes across the grounding lines in drainage 9 and 11

\begin{tabular}{ccccccc}
\hline Region & $\begin{array}{c}\text { Gate } \\
\text { No. }\end{array}$ & $W$ & $\bar{U}$ & $\bar{H}$ & $\theta$ & $F$ \\
& $\mathrm{~m}$ & $\mathrm{~m} \mathrm{a}^{-1}$ & $\mathrm{~m}$ & $\circ$ & $\mathrm{Gta}^{-1}$ \\
\hline
\end{tabular}

Drainage 9

$\begin{array}{rrrrll}1 & 6228 & 127.26 & 892 & 90 & 0.152 \\ 2 & 16336 & 73.26 & 987 & 90 & 1.056 \\ 3 & 10360 & 139.96 & 1165 & 90 & 1.511 \\ 4 & 4978 & 129.16 & 1218 & 90 & 0.700 \\ 5 & 10393 & 79.25 & 1248 & 90 & 0.919 \\ 6 & 4723 & 50.05 & 1272 & 90 & 0.269 \\ 7 & 3567 & 78.05 & 1136 & 90 & 0.285 \\ 8 & 8408 & 72.86 & 1216 & 29.49 & 0.331 \\ 9 & 8055 & 113.52 & 1040 & 90 & 0.858 \\ 10 & 12735 & 134.72 & 1610 & 90 & 2.492 \\ 11 & 9098 & 144.12 & 1402 & 90 & 1.658 \\ 12 & 5229 & 100.28 & 1847 & 90 & 0.874 \\ 13 & 9257 & 86.75 & 1454 & 66.45 & 0.965 \\ 14 & 5369 & 89.02 & 917 & 90 & 0.399 \\ 15 & 3720 & 74.17 & 2007 & 90 & 0.504 \\ 16 & 15956 & 61.84 & 919 & 90 & 0.825 \\ 17 & 11852 & 88.18 & 1021 & 90 & 0.971 \\ 18 & 24546 & 75.70 & 1495 & 90 & 2.527 \\ 19 & 35203 & 87.16 & 1795 & 90 & 2.531 \\ & & & & & 19.8 \pm 2.0\end{array}$

Drainage 11

$\begin{array}{rrrrll}1 & 3186 & 71.56 & 760 & 90 & 0.157 \\ 2 & 6054 & 56.76 & 308 & 90 & 0.096 \\ 3 & 4113 & 96.75 & 1035 & 90 & 0.373 \\ 4 & 3204 & 62.13 & 796 & 90 & 0.143 \\ 5 & 3946 & 70.58 & 900 & 90 & 0.227 \\ 6 & 12439 & 451.16 & 896 & 90 & 4.597 \\ 7 & 13590 & 114.20 & 873 & 90 & 0.689 \\ 8 & 11265 & 36.59 & 848 & 90 & 0.291 \\ 9 & 6517 & 20.70 & 793 & 90 & 0.089 \\ 10 & 15544 & 142.74 & 1925 & 45.55 & 2.540 \\ 11 & 7762 & 132.83 & 2737 & 90 & 2.353 \\ 12 & 12834 & 149.33 & 2035 & 90 & 3.573 \\ & & & & & 15.1 \pm 1.5\end{array}$

Notes: $W$ is gate width, $\bar{U}$ is average surface velocity, $\bar{H}$ is mean ice thickness, $\theta$ is angle between flow direction and gate, and $F$ is ice flux, converted using a column-averaged ice density of $910 \mathrm{~kg} \mathrm{~m}^{-3}$.

Together, these errors yield an overall uncertainty of up to $100 \mathrm{~m}$ in ice thickness. The resultant error in ice fluxes across the grounding lines is given as $10 \%$.

\section{Total accumulation}

We estimate total accumulation by averaging surface accumulation datasets by Vaughan and others (1999) and M.B. Giovinetto (Giovinetto and Zwally (2000), modified by Giovinetto) (hereafter, Vaughan and Giovinetto compilations respectively). The total accumulations of drainages 9 and 11 (Table 2) are equal to their area multiplied by the annual accumulation rate averaged over the area. The error of the annual accumulation is assumed to be $10 \%$, and the error of the drainage area $5 \%$, so the error in the catchment-wide accumulation totals is $11.2 \%$ (Wen and others, 2006, 2007).

\section{MASS BUDGET OF THE GROUNDED ICE}

If we assume a steady-state glacier system, the mass output (discharge) $\left(\Psi_{\text {out }}\right)$ from an area is equal to the sum of the
Table 2. Accumulation, ice fluxes and mass budgets $\left(\mathrm{Gta}^{-1}\right)$ for drainages 9, 10 and 11 and the whole grounded ice

Drainage 9 Drainage 10 Drainage $11 \begin{gathered}\text { Whole } \\ \text { grounded ice }\end{gathered}$

\begin{tabular}{lrrrr}
\hline$\Psi_{\text {out }}$ & $19.8 \pm 2.0$ & $54.0 \pm 5.4$ & $15.1 \pm 1.5$ & $88.9 \pm 8.9$ \\
$\oint_{S} A \mathrm{~d} S$ & $17.3 \pm 1.9$ & $51.4 \pm 5.8$ & $16.0 \pm 1.8$ & $84.8 \pm 4.2$ \\
Mass budget & $-2.5 \pm 2.8$ & $-2.6 \pm 7.9$ & $0.9 \pm 2.3$ & $-4.2 \pm 9.8$ \\
\hline
\end{tabular}

inflow $\left(\Psi_{\text {in }}\right)$ and the integrated accumulation over the area (Budd and Warner, 1996; Fricker and others, 2000b):

$$
\Psi_{\text {out }}=\Psi_{\text {in }}+\oint_{s} A \mathrm{~d} S,
$$

where $A$ is annual accumulation rate.

\section{Mass budget of the whole grounded ice}

Calculating the mass budget of the grounded ice as a whole, $\Psi_{\text {out }}$ in Equation (1) is the ice flux across the grounding line, $\Psi_{\text {in }}$ is 0 and $\oint_{S} A \mathrm{~d} S$ is the sum of the total accumulations for drainages 9,10 and 11 .

We evaluate Equation (1) using the results presented in Tables 1 and 2. We find that $\Psi_{\text {out }}=88.9 \pm 8.9 \mathrm{Gta}^{-1}$, and $\Psi_{\text {in }}+\oint_{S} A d S=84.8 \pm 4.2 \mathrm{Gta}^{-1}$ (Table 2). This implies that LAS grounded ice has a statistically insignificant imbalance of $-4.2 \pm 9.8 \mathrm{Gta}^{-1}$, corresponding to $-5 \pm 12 \%$ of the total accumulation.

\section{Mass budgets of three drainages}

Table 2 lists the accumulation, ice fluxes and mass budgets for drainages 9, 10 and 11. Drainage 11 has an imbalance of $0.9 \pm 2.3 \mathrm{Gta}^{-1}$, while drainages 9 and 10 tend towards a negative imbalance, though none of the estimated balance magnitudes are statistically different from zero. Notice that the total area of the grounded ice in drainages 9 and 11 is $371955 \mathrm{~km}^{2}$, or $27.7 \%$ of the entire LAS grounded ice, while the total annual accumulation and ice flux across the grounding lines of these sectors is $40 \%$ of the entire grounded LAS. Therefore, drainages 9 and 11 are important components of the system-wide mass balance.

\section{Mass budgets upstream and downstream of the LGB traverse}

Table 3 gives the mass budgets of the three drainages upstream (as discussed by Wen and others, 2006) and downstream of the Australian LGB traverse. Data used to subdivide the basin include ANARE program ice thicknesses and GPS velocities (Higham and Craven, 1997; Craven and others, 2001; Kiernan, 2001). GPS velocities are supplemented by InSAR velocities. Unlike ice streams draining into the Ross Ice Shelf or the Amundsen Sea, the combined mass budgets of the six upstream and downstream sectors are insignificantly different from zero. That said, there is some variability between the upstream and downstream regions. Sub-basins upstream of drainages 9 and 11 and downstream of drainages 9 and 10 may have a negative imbalance, while regions upstream of drainage 10 and downstream of drainage 11 have a positive imbalance. The upstream region as a whole has an imbalance of $4.4 \pm$ $6.3 \mathrm{Gta}^{-1}$, while the downstream region has a negative imbalance, $-8.9 \pm 9.9 \mathrm{Gta}^{-1}$. 
Table 3. Accumulation, ice fluxes and mass budgets $\left(\mathrm{Gta}^{-1}\right)$ for drainages 9,10 and 11 upstream and downstream of the ANARE LGB traverse

\begin{tabular}{|c|c|c|c|c|c|c|}
\hline & \multicolumn{2}{|c|}{ Drainage 9} & \multicolumn{2}{|c|}{ Drainage 10} & \multicolumn{2}{|c|}{ Drainage 11} \\
\hline & Upstream & Downstream & Upstream & Downstream & Upstream & Downstream \\
\hline$\Psi_{\text {in }}+\oint_{S} A \mathrm{~d} S$ & $3.5 \pm 0.4^{*}$ & $17.9 \pm 1.6^{\dagger}$ & $41.0 \pm 4.6^{*}$ & $45.5 \pm 2.1^{\dagger}$ & 8.0 & \\
\hline$\Psi_{\text {in }}$ & $4.1 \pm 0.2$ & $19.8 \pm 2.0$ & $35.2 \pm 1.8$ & $54.0 \pm 5.4$ & $8.8 \pm 0.4$ & $15.1 \pm 1.5$ \\
\hline Mass budget & $-0.7 \pm 0.4$ & $-1.9 \pm 2.6$ & $5.9 \pm 4.9$ & $-8.5 \pm 5.8$ & $-0.8 \pm 1.0$ & $1.7 \pm 1.8$ \\
\hline
\end{tabular}

${ }^{*} \Psi_{\text {in }}$ is 0 for sub-basins upstream of the ANARE LGB traverse.

†'Eual to accumulation plus inflow $\left(\Psi_{\text {in }}\right)$ through the LGB traverse.

\section{CONCLUSIONS AND DISCUSSION}

In this paper, we calculate the ice fluxes across the grounding lines of drainages 9 and 11, along with the drainage surface accumulation fluxes. We also calculate the mass budget of the entire grounded ice region of the LAS.

The ice fluxes across the grounding lines of drainages 9 and 11 are $15.1 \pm 1.5 \mathrm{Gta}^{-1}$ and $19.8 \pm 2.0 \mathrm{Gta}^{-1}$ respectively. The entire LAS grounded ice is approximately in balance, with a mass budget of $-4.2 \pm 9.8 \mathrm{Gta}^{-1}$. Drainages 9,10 and 11 are also nearly in balance, with mass budgets of $-2.5 \pm 2.8 \mathrm{Gta}^{-1},-2.6 \pm 7.8 \mathrm{Gta}^{-1}$ and $0.9 \pm 2.3 \mathrm{Gta}^{-1}$ respectively, though there is some variability between adjacent glaciers upstream and downstream of the ANARE LGB traverse. Although the total grounded-ice area of drainages 9 and 11 covers $27.7 \%$ of the entire LAS grounded ice, the total annual accumulation and the total ice flux across the grounding line of these drainages accounts for $40 \%$ of the grounded LAS.

Using the integrated approach (ISMASS Committee, 2004), Zwally and others (2005) calculated the net mass balance of the grounded ice in the LAS to be only $0.3 \mathrm{Gta}^{-1}$ from 1992 to 2002. Wen and others (2006) report an overall thickening trend in the basin from 1992 to 2003 of $9.0 \pm 1.3 \mathrm{Gta}^{-1}$, based on altimetry-derived ice-thickness changes at the grounded LAS based on Davis and others' (2005) supporting online material. In this paper, we estimate the mass budget of the grounded ice to be $-4.2 \pm 9.8 \mathrm{Gt} \mathrm{a}^{-1}$ using a component approach (ISMASS Committee, 2004). Some of the differences may arise because of different estimates of the net surface balance. Zwally and others (2005) estimated the total accumulation of the grounded ice in the LAS to be $79.61 \mathrm{Gta}^{-1}, 5 \mathrm{Gta}^{-1}$ less than our result. Possible explanations include: (1) they used surface annual accumulation data compiled by Giovinetto and Zwally (2000), while we used the average of Vaughan and Giovinetto compilations; and (2) there are some differences in the grounding line position and the coverage of the LAS between the two studies. The remaining differences are more difficult to explain. However, we believe our sectorby-sector analysis of LAS mass balance gives a more complete picture of basin properties and offers a contrast to West Antarctica where there seem to be strong flowregime-to-flow-regime mass-balance differences.

\section{ACKNOWLEDGEMENTS}

This work is supported by the National Natural Science Foundation of China (grants No. 40730526, 40471028, 40476005), the Shu Guang project (grant No. 05SG46) and
NASA's Polar Oceans and Ice Sheets Program. We thank M.B. Giovinetto and D.G. Vaughan for providing accumulation compilations. In particular, M.B. Giovinetto provided a new modified (as yet unpublished) accumulation compilation.

\section{REFERENCES}

Allison, I. 1979. The mass budget of the Lambert Glacier drainage basin, Antarctica. J. Glaciol., 22(87), 223-235.

Bentley, C.R. and M.B. Giovinetto. 1991. Mass balance of Antarctica and sea level change. In Weller, G., C.L. Wilson and B.A.B. Severin, eds. International Conference on the Role of the Polar Regions in Global Change: proceedings of a conference held June 11-15, 1990 at the University of Alaska Fairbanks. Vol. 2. Fairbanks, AK, University of Alaska. Geophysical Institute/ Center for Global Change and Arctic System Research, 481-488.

Bindschadler, R., P.L. Vornberger and S. Shabtaie. 1993. The detailed net mass balance of the ice plain on Ice Stream B, Antarctica: a geographic information system approach. J. Glaciol., 39(133), 471-482.

Budd, W.F. and R.C. Warner. 1996. A computer scheme for rapid calculations of balance-flux distributions. Ann. Glaciol., 23, 21-27.

Connolley, W.M. and J.C. King. 1993. Atmospheric water-vapour transport to Antarctica inferred from radiosonde data. Q.J. R. Meteorol. Soc., 119(510), 325-342.

Craven, M., M. Higham and A. Brocklesby. 2001. Ice thicknesses and surface and bedrock elevations from the Lambert Glacier basin traverses 1990-95. Antarct. CRC Res. Rep. 23.

Davis, C.H., Y. Li, J.R. McConnell, M.M. Frey and E. Hanna. 2005. Snowfall-driven growth in East Antarctic ice sheet mitigates recent sea-level rise. Science, 308(5730), 1898-1901.

Fricker, H.A., G. Hyland, R. Coleman and N.W. Young. 2000a. Digital elevation models for the Lambert Glacier-Amery Ice Shelf system, East Antarctica, from ERS-1 satellite radar altimetry. J. Glaciol., 46(155), 553-560.

Fricker, H.A., R.C. Warner and I. Allison. 2000b. Mass balance of the Lambert Glacier-Amery Ice Shelf system, East Antarctica: a comparison of computed balance fluxes and measured fluxes. J. Glaciol., 46(155), 561-570.

Fricker, H.A. and 9 others. 2002. Redefinition of the Amery Ice Shelf, East Antarctica, grounding zone. J. Geophys. Res., 107(B5), 2092. (10.1029/2001JB000383.)

Giovinetto, M.B. and H.J. Zwally. 2000. Spatial distribution of net surface accumulation on the Antarctic ice sheet. Ann. Glaciol., 31, 171-178.

Hambrey, M.J. and J.A. Dowdeswell. 1994. Flow regime of the Lambert Glacier-Amery Ice Shelf system, Antarctica: structural evidence from Landsat imagery. Ann. Glaciol., 20, 401-406.

Higham, M. and M. Craven. 1997. Surface mass balance and snow surface properties from the Lambert Glacier basin traverses 1990-94. Antarct. CRC Res. Rep. 9. 
ISMASS Committee. 2004. Recommendations for the collection and synthesis of Antarctic ice sheet mass balance data. Global Planet. Change, 42(1-4), 1-15.

Jezek, K.C. 2002. RADARSAT-1 Antarctic Mapping Project: changedetection and surface velocity campaign. Ann. Glaciol., 34, 263-268.

Jezek, K.C. 2003. Observing the Antarctic ice sheet using the RADARSAT-1 synthetic aperture radar. Polar Geogr., 27(3), 197-209.

Kiernan, R. 2001. Ice sheet surface velocities along the Lambert Glacier basin traverse route. Antarct. CRC Res. Rep. 23.

Liu, H., K.C. Jezek and B. Li. 1999. Development of an Antarctic digital elevation model by integrating cartographic and remotely sensed data: a geographic information system based approach. J. Geophys. Res., 104(B10), 23,199-23,213.

Payne, A.J., A. Vieli, A. Shepherd, D.J. Wingham and E. Rignot. 2004. Recent dramatic thinning of largest West Antarctic ice stream triggered by oceans. Geophys. Res. Lett., 31(23), L23401. (10.1029/2004GL021284.)

Rignot, E. 2002. Mass balance of East Antarctic glaciers and ice shelves from satellite data. Ann. Glaciol., 34, 217-227.

Shepherd, A., D. Wingham and E. Rignot. 2004. Warm ocean is eroding West Antarctic Ice Sheet. Geophys. Res. Lett., 31(23), L23404. (10.1029/2004GL021106.)

Solomon, S. and 7 others, eds. 2007. Climate change 2007: the physical science basis. Contribution of Working Group I to the Fourth Assessment Report of the Intergovernmental Panel on Climate Change. Cambridge, etc., Cambridge University Press.

Thomas, R. and 17 others. 2004. Accelerated sea-level rise from West Antarctica. Science, 306(5694), 255-258.
Thompson, S.L. and D. Pollard. 1997. Greenland and Antarctic mass balances for present and doubled atmospheric $\mathrm{CO}_{2}$ from the GENESIS Version-2 global climate model. J. Climate, 10(5), 871-900.

Vaughan, D.G., J.L. Bamber, M. Giovinetto, J. Russell and P.R. Cooper. 1999. Reassessment of net surface mass balance in Antarctica. J. Climate, 12(4), 933-946.

Wang, Y., J. Wen, J. Liu, K.C. Jezek and B. Csathó. 2006a. Amery Ice Shelf DEM and the distribution of marine ice. Chinese J. Polar Sci., 17(2), 117-123.

Wang, Y., J. Wen and J. Liu. 2006b. Rapid changes of the Antarctic Ice Sheet and glaciers. Chinese J. Polar Res., 18(1), 63-74. [In Chinese with English summary.]

Wen, J. 1998. International study on Antarctic Ice Sheet and sea level change: a review. Adv. Earth Sci., 15(5), 586-591. [In Chinese with English summary.]

Wen, J., K.C. Jezek, A.J. Monaghan, B. Sun, J. Ren and P. Huybrechts. 2006. Accumulation variability and mass budgets of the Lambert Glacier-Amery Ice Shelf system, East Antarctica, at high elevations. Ann. Glaciol., 43, 351-360.

Wen, J., K.C. Jezek, B. Csathó, U.C. Herzfeld, K.L. Farness and P. Huybrechts. 2007. Mass budgets of the Lambert, Mellor and Fisher Glaciers and basal fluxes beneath their flowbands on Amery Ice Shelf. Sci. China D, 50(11), 1693-1706.

$\mathrm{Wu}$, X. and K.C. Jezek. 2004. Antarctic ice-sheet balance velocities from merged point and vector data. J. Glaciol., 50(169), 219-230.

Zwally, H.J. and 7 others. 2005. Mass changes of the Greenland and Antarctic ice sheets and shelves and contributions to sealevel rise: 1992-2002. J. Glaciol., 51(175), 509-527. 